\title{
'Efficiency' and 'Vocationalism' as Structuring Principles of Industrial Education in the USA
}

\author{
Philipp Gonon
}

Received: 8 July 2008 / Accepted: 26 September 2008 /

Published online: 5 November 2008

(C) Springer Science + Business Media B.V. 2008

\begin{abstract}
The aim of this paper, based on a comparative viewpoint from an European outsider perspective, is to present a brief historical reconstruction of the pedagogical and educational political discussion about education for the industrial sector in America. The discussion was triggered by the emerging idea that one of the principal tasks of education should be to prepare youth most effectively for their upcoming work life. It followed that the constitution and role of the American schools to achieve this purpose were widely debated early in the twentieth century by eminent pedagogues. Some of these pedagogues argued for an American education system that also developed vocational abilities and skills, whereas others favoured only the development of general knowledge. During the course of this dispute, across the first half of the twentieth century, other key issues were brought forward such as whether this much vaunted vocational education should be enacted in comprehensive schools or whether other kinds of schools should be established for these purposes. Furthermore, another model that resembled the German vocational system was also proposed through this period. However, ultimately and unlike in Germany, a dual model of vocational education and training characterised by an interlocking of school-based instruction and workplace training has not managed to establish itself as a discrete educational sector in America. Currently, education for industry is provided mainly in schools and tends to be oriented towards the criteria of efficiency and vocationalism.
\end{abstract}

Keywords History of vocational education and training · Vocationalism - Efficiency · Reform pedagogy · German apprenticeship system

P. Gonon $(\bowtie)$

Berufsbildung am ZHSF (Zürcher Hochschulinstitut für Schul- und Fachdidaktik),

Beckenhofstrasse 35, CH-8006 Zürich, Switzerland

e-mail: gonon@igb.uzh.ch 


\section{Introduction}

In German-speaking countries, international comparative studies on vocational education and training usually focus on either England and France (e.g. Deissinger 1994; Koch 1998; Greinert 2005) or on perspectives of educational politics in Europe (Münk 2006). Even Japan seems to be of more interest to German-speaking vocational pedagogues than America (Georg 1992). This lack of interest can be explained by the fact that the American system of vocational education and training is not considered as being exemplary (Gonon 1998). Unlike with higher education, in the area of vocational education Germany can offer recommendations to America, but not the other way around it is assumed. This was already the case at the beginning of the twentieth century when Georg Kerschensteiner ${ }^{1}$ gave a lecture tour in the USA and attracted interest of a wide audience by propagating the German vocational education model (Kerschensteiner 1911). Indeed, until today, knowledge transfer in vocational pedagogy mostly occurs from Germany to the America, than the other way around (Schütte 2001). Certainly, only few German comparative studies identified positive aspects in the American system, beside its obvious deficits (Monsheimer 1968).

Generally, the presentation of these differences serves to point out distinct and possibly new ways of conceptualising problems and responses. Under these circumstances, a nation-specific discourse will be presented first, which outlines the circumstances leading to the present situation of vocation-oriented education in America. Here, my main interest does not focus on system issues or institutional and socio-historical differentiation, but in the reconstruction of debates in connection with contingent developments that can be described as alternative options. This is followed by an elaboration of how the twin concepts of efficiency and vocationalism have progressed within the American education system.

\section{Vocational Dimensions of Education and Efficiency as Focal Points}

In Paul Monroe's Cyclopaedia of education at the beginning of the twentieth century, education - no matter in what form - is said to be vocational. Thus, the entry for "vocational education" adheres the following passage: "In a certain sense all education is vocational in that it aims to prepare one for the most efficient and satisfactory performance of the activities of life" (Monroe 1913, p. 740). When talking about vocational education, it has to be considered that the expression "vocational schooling" solely alludes to the vocational education within schools, whereas "vocational education" includes vocational trainings outside vocational schools (cf. the German school system), for example, in firms and other kinds of training schools.

Even general education - or "liberal education" - is said to be vocational because it aims at the efficient application of one's acquired knowledge. In his article

\footnotetext{
${ }^{1}$ Georg Kerschensteiner (1854-1932), a German pedagogue and originator of the so-called "Arbeitsschule" (work school), condemned the one-sided geared education. His educational approach stimulated the thought of vocational education. Today Kerschensteiner is deemed to be one of the cofounders of the German vocational education system (Gonon 2002).
} 
"Culture and Cultural Values", in the same Cyclopaedia, John Dewey ${ }^{2}$ challenged the concept of culture advanced by the highly acclaimed Matthew Arnold: another man of letters and a school reformer. Dewey (1911) criticised Arnold's endeavour to familiarise learners only with the very best a culture had to offer, arguing that this approach was too narrow and one-sided (p. 238). According to Dewey's perspective, modern culture also included "manual and industrial activities". Surely, it is not new to stress that any form of education is related to vocation and that the world of work is a part of culture. However, Dewey's argument is relevant in the present context insofar as it has essentially shaped the thematic profile of, and the language used to describe the relationship of education and the world of work right up to the present day. On the one hand, education is considered being a question of efficiency, but on the other hand, the need to integrate education into a new context is understood to require its "vocationalisation". To quote from Monroe's Cyclopaedia again: "Even in the classical period, when the conception of liberal education was formed, it aimed to produce the liberally educated man or the man efficient in the application of his knowledge" (Monroe 1913, p. 740 cited as seen).

The term "efficiency" refers to the actual output proportional to the total input in any kind of system. In terms of education, efficiency is gained by maximum output from a given input (e.g. class size, teaching-materials etc.), or else an intended output (like graduation rates etc.) being achieved by minimum input. Generally, education is said to be efficient if it is successfully geared to current social and economic developments and if it enables learners to apply the acquired knowledge and skills effectively when required.

\section{Efficiency as a Parallel of Education and Industrial Production}

The idea of efficient application of knowledge draws on an analogy with industrial production, as several pedagogues have proposed. In their publication "Efficiency in Education", Wright and Allen (1929) set up the following parallels of the production and educational process:

\begin{tabular}{ll}
\hline The manufacturing process & $\begin{array}{l}\text { The educational process } \\
\text { 1. Utilises material }\end{array}$ \\
$\begin{array}{ll}\text { 1. Utilises learners } \\
\text { 2. Subjects the material to mechanical operations } \\
\text { and processes }\end{array}$ & $\begin{array}{l}\text { 2. Subjects the learner to educational methods and } \\
\text { procedures }\end{array}$ \\
$\begin{array}{ll}\text { 3. Changes the characteristics of the material as to } & \text { 3. Changes the characteristics of the learner as to } \\
\text { form, shape, physical or chemical properties } & \text { attitudes, ideals, and possession of skills }\end{array}$ \\
$\begin{array}{ll}\text { 4. Turns out a manufactured product ready for the } & \text { 4. Turns out an individual with additional abilities } \\
\text { market } & \text { for some form of social adjustment and service }\end{array}$
\end{tabular}

(Wright and Allen 1929, p. 5)

\footnotetext{
${ }^{2}$ John Dewey (1859-1952), who was an American psychologist, philosopher and social reformer, helped to establish along with Charles Sanders Peirce (1839-1914) and William James (1842-1910) the philosophical concept of pragmatism. Pragmatism is a founded doctrine where the truth of a statement is attested by its practical consequences. In terms of pedagogic he argued that pupils should not be regarded as objects of teaching but as subjects of learning. Dewey also wanted to attach the importance of pedagogic in the education of teachers. Therefore he got involved with questions of vocational education. Kerschensteiner and Dewey met in the year 1911 in New York (Gonon 2000).
} 
This parallelism of education and industrial production is also found in more recent publications. In their 1992 publication "The Double Helix of Education and the Economy", Berryman and Bailey distinguish between effective and ineffective learning and argue that traditional workplaces feature a similar structure-like ineffective learning:

Characteristics of ineffective learning

- Limited transfer

- Learners are passive vessels

- Bond between stimuli and correct response

- Emphasis on getting the right answer
Characteristics of traditional workplaces

- Narrowly defined jobs and tasks

- Passive order-taking in a hierarchical work organisation

- Emphasis on specific responses to a limited number of problems

- Rather than improving the performance a task has to be done

(Berryman and Bailey 1992, p. 112)

In Berryman and Bailey's (1992) view, both traditional workplaces, as well as outmoded ways of schooling, are characterised by a narrow definition of tasks, a limited learning environment and hierarchical structures that force workers and learners into passive roles and, thereby, offer little incentive to engage in independent learning and problem solving. Much earlier, it was also argued that a main challenge of the twentieth century was to "reduce or eliminate waste-waste of time, effort, money and lives" (Leake 1913, p. 7), making efficiency a central tenant. Compared with industrial production, efficiency in the educational sector was similarly defined in terms of a reduction of waste of time, effort and money. So, discussions about the educational worth of vocational education in terms of efficiency has a long legacy.

\section{Efficiency as a Historical Argument of Reform Pedagogy}

As the discussion above suggests, efficiency was a topic in early twentieth century pedagogy as much as in economy as in the then emerging management theory. The philosopher and pedagogue John Dewey relied on Charles W. Eliot for his conceptions. Eliot ${ }^{3}$, who taught at Harvard; published in 1906 "Education for Efficiency and the New Definition of the Cultivated Man" in which he proposed that education should be directed towards work. Indeed, he understood efficiency to mean "effective power for work and service during a healthy and active life" (Eliot 1906, p. 1). Furthermore, he expected every woman and man to strive in order to reach this form of power. His argument for this purpose is rooted in a sensualistic tradition, which becomes clear in his claim that during childhood and youth it was necessary to invest in the training of the bodily senses and the care of the body. In addition, children should be trained in a variety of subjects and "in as large a variety of mental processes as possible, and to establish as many useful mental habits as possible" (ibid.). Such an "initiation" enabled youths and adults later on to master

\footnotetext{
${ }^{3}$ Charles William Eliot (1834-1924) was an American educator and president of Harvard, near Boston, who turned Harvard under his administration from a small college into an excellent research university. Therefore he introduced several reforms like the enrichment of the curriculum, the enlargement of the faculty and the requirement of written exams. He also supported the attempt to establish a women's college and fostered the development of Radcliffe College. Eliot was the longest university president in Harvard's history. After his retirement in 1909 took interest in public affairs and became a member of the General Education Board.
} 
new subjects in a brief period of time, it was claimed. Eliot also argued for sentiment being the "real motive power in every human life, and in national life" (ibid). Therefore, education needed to involve a person's whole character. Only if a person's whole character and activity was determined by some sentiment or passion, was it possible to reach the highest level of human efficiency (Eliot 1906). This kind of reasoning conveys that education necessarily encompasses not merely a brief period of time in childhood and youth, but a person's whole life. Aside from offering opportunities for a consolidation of everything learned early in life continuing education in adult years was also considered to be beneficial for society as a whole.

Irving King, a professor at the State University of Iowa at this time, also was engaged in the discussion of efficiency. Explicitly referring to Dewey and Kerschensteiner, he argued for schools as institutions for character-building that should cultivate manual work and teamwork, and include a playful element in class. As social centres, schools should serve social progress by incorporating aspects of life from outside the school (King 1913, p. 266 ff). His particular contribution demonstrates that (classical) postulates of reform pedagogy_like manual work and the inclusion of extracurricular aspects - could easily serve as arguments in the efficiency discourse.

\section{Manual Work in Elementary School as a Contribution to External Efficiency}

In the claims presented so far, it is possible to distinguish between 'internal' and 'external' efficiency. Internal efficiency simply means that some measures are considered more efficient than others, because they are better suited to further learning and education. Additionally, 'external' references also play a role, notably to the world of work. Education is efficient if it meets the requirements of professional knowledge and skills. For this reason, educational and administrative progressives called for adequate consideration of vocational needs at school. Though literature and the arts were undisputedly part of the curriculum, practical matters too should be included to serve the needs of future workers and their tasks in the industry and the service sector (Davenport 1914). In other words, the traditional school system was criticised for its implicit assumption that all children and youths need a brief period of general education only, irrespective of their later occupation, and that the populace had no need of continuing education. The aim of manual work or, as it came to be called later on, 'industrial arts', should be to provide children and youths with an intelligent understanding of industrial production processes and of "the nature of industrial society" (Copa and Bentley 1991, p. 900). With this reference to external efficiency, understood as adequate provision for the world of work in general schooling and integration of manual work in the curricula, vocation-oriented education appeared on the American educational reform agenda (Herbst 1996, p. 117).

According to Bennett (1937), vocation-oriented education was not merely a matter of enriching general education with handiwork, but its integration in the general schooling curriculum served the purpose of technical education and training. Manual skills could be imparted more effectively in general schools than in the traditional apprenticeships in firms (p. 46). Consequently, Bennett established a link between manual work and a vocation-oriented educational reform as well (p. 550). It was widely agreed that efficient education per se needed to consider the require- 
ments of the world of work. Manual work in the general school system lent itself well as a contribution to vocation-oriented education, with both work-related and more general benefits as Davenport (1914) suggested.

\section{Vocationalism and Vocational Schools as Contributions to 'Social Efficiency'}

A more comprehensive concept of efficiency was advanced by David S. Snedden ${ }^{4}$, who before becoming a fellow professor of Dewey's at the Teachers College at Columbia University, had been a teacher, a school principal and superintendent. As one of the most prominent progressive educators of his time, Sneeden had taken an interest in questions of vocational education since early on, especially elaborating his concept of 'social efficiency'. He expected 'social efficiency' to advance society as a whole "by making its members more vocationally useful and socially responsible" (Snedden 1910, p. 3). Efficiency was, therefore, closely tied to social responsibility and focussed on the prospective social position of youth. Everybody should be trained for a specific role in social fabric, which included all pupils being confronted with vocation-related knowledge, skills and attitudes, he argued. He justified this view of social efficiency in terms of democratic needs. Indeed, he expected a curriculum based on this concept to enable students to survive and advance in their work and social life. The ideas of social efficiency persisted in American social thought, and resurfaced as a topic in the life adjustment movement in the 1940s and 1950s (Drost 1967, p. 100).

The starting point for these considerations can be found in the concerns about directing all subjects to one centre of interest. It was for this reason that some advocates of social efficiency, like Davenport, argued for a comprehensive high school. Snedden, however, wanted to establish separate schools for each profession (Snedden 1910, p. 129 ff.), because - in contrast to liberal education with its focus on the consumer-vocational education aimed at the education of the producer. According to Snedden, there was no discrepancy between efficiency and democracy, with both being served best by the establishment of a multiplicity of schools providing occupationally-specific vocational education. From this perspective, vocation-oriented continuation schools and the German model of vocational education became to be of interest to North American educational reformers.

\section{Vocational Schools as Alternatives and Complement to Comprehensive High Schools}

Given the apparent similarity of their concerns it is understandable that David Snedden was surprised when John Dewey argued against an education system

\footnotetext{
${ }^{4}$ David Samuel Snedden (1868-1951) was one of the most influential educators of the Progressive Era. His ambition was to design an educational programme which adjusted the pretentions of modern society with the ability and interest of children. For several years he served as a teacher and superintendent at schools in California. Afterwards he taught as assistant professor in Stanford, as adjunct professor at the Teachers College of Columbia University and became the first State Commissioner of Education in Massachusetts. He is also known as the founder of educational sociology.
} 
characterised by a number of different schools types. In contrast to Snedden's vision of an educational system in which general and vocational schooling was clearly separated, Dewey held to the idea of a single school type with integrated components of vocational education. Snedden's expectation was that if vocational education was integrated into the system of general - or liberal-education, it would soon adapt to the dominant academic tradition (Snedden 1910, p. 132). However, Dewey considered such a separation of vocational and general education would lead to restrictions on both educational sectors. In Dewey's opinion, Snedden's position was too much influenced by the idea of social predestination, making this form of education more about societal reproduction than change. Dewey (1916) held that workers should not adapt to existing structures and submit to an industrial regime, but instead 'transform' the system. Snedden countered that Dewey's system inhibited access to education for many young Americans, and that it could, therefore, hardly be said to contribute to either democracy or efficiency. Only a scomprehensive vocationalisation of the education system might enable every single member of society to realise its full potential.

However, Snedden was also criticised because his goals could be better reached with a model in which apprenticeships in firms are supplemented by school instruction, rather than exclusively with schooling. Yet, it may well be the case that Snedden was not completely averse to the idea of basing vocational education on both-firms and schools-like in the German system. Even though some local initiatives were constituted like a dual model of vocational education (Cooley 1912), it was eventually the system with comprehensive high schools in which vocational content was integrated into the existing curricula that found its way into the legislation in the 1920s. Thus, a 'hybridisation' of the curriculum was established in America, resulting in the combination of general and vocational content within a single educational institution (Kliebard 1986, p. 213 ff.).

\section{Examination of the German Apprenticeship System}

The aspect of efficiency was also dominant in the question of whether an apprenticeship based system should be introduced through which in-firm training of vocational skills was combined with school instruction. It was held that industrial incompetence was a major problem and a serious cause of economic loss in America and, therefore, because of the low levels of workplace competence, support by the educational system was necessary to develop effective vocational skills. Indeed, at this time, taking additional classes at evening schools was considered important as the division of labour prevalent in manufacturing left employees with little scope for in-firm learning and training. In these discussions, the German system of vocational education with its dual model of vocational education and training was often taken as a point of reference.

Leake (1913) assumed that the apprenticeship system might develop in certain occupational areas in America in similar to ways to how this occurred in Europe, where some industry sectors had seen a revival of in-firm apprenticeship training. However, the higher education standard of German workers was not considered to be a consequence of the national system of vocational education, but as a result of the overall highly developed education system (Leake 1913, p. 182). Thus, Leake 
warned against adopting the German apprenticeship system uncritically. Germany, in particular, could serve as role model for the fact that industrial education was a comprehensive task of industry and schooling. The most important lesson to be learned from Germany was that industrial workers were better served by the education system than in other countries (King 1913, p. 188 ff.).

Though this discussion is only briefly outlined here, it follows that the design and direction of American vocational education was considered within terms of matters of efficiency. Consequently, two alternatives emerged: the vocationalisation of the school system versus an apprenticeship model following the German vocational education system, although it was the former that ultimately prevailed.

\section{Vocationalism as a Constitutive Element in School Curricula: How Vocational Education Found its Way into Schools}

In the debate about the form of vocational education, it was Dewey who eventually won over Snedden (Knoll 1993). Instead of separate vocational schools or a dual model of vocational education, like in Germany, an integrated high school system was established. However, in American pedagogical history books, Snedden as an advocate of vocationalism has been considered the winner of this debate. While his preferred model with two different school types was claimed not to have been possible because of deficiencies in American workplaces, the high school curricula was divided into general education and vocational education content (Kliebard 1999, p. 146 ff.). According to Kliebard (1999), the basis for the vocationalisation of school curricula in the USA was laid in the 1920s, with efficiency as the main criterion. Since then, it has been virtually unthinkable to ignore the argument of workplace success in debates on educational reforms (Kliebard 1999, p. 171 ff.).

Much to the regret of many pedagogues and historians of education, external efficiency - understood as a relation to the world of work-has gained too much importance as a yardstick for reforms. At first, the vocational education movement was considered to be effective (Lazerson and Grubb 1974, pp. IX-X), but later on, the notion of 'vocationalism' has come to be met with scepticism in the Englishspeaking world. Vocationalism means that the education system as a whole is constantly to be reminded to orient towards the world of work. The education system should mainly have a preparatory function for the world of work by training specific skills and conveying a positive attitude towards work. The focus was, therefore, clearly on manual training justified, on the one hand, by the general and educational welfare of the child and, on the other hand, with the necessity of acquiring relevant skills for the future working life. This rationale ties in with Kerschensteiner's idea of describing his Arbeitsschule (literally 'work school') in Germany as a school for character building, thereby extending the traditional purpose of the schools to new (i.e. workplace) content (Gonon 2000). Even though there has been an ambiguous appraisal of the effects of introducing handiworks into the curriculum, this development has nevertheless prepared the ground for further tendencies towards vocationalism in the American education system (Kliebard 1999, p. 26 ff.).

The drift towards vocationalism was subsequently and further nourished by the argument of the demand for highly qualified workers. This argument was first 
advanced by employer associations, but the idea of a stronger vocational orientation in the education system instead of the failed introduction of an apprenticeship system modelled after Germany soon also caught on with labour unions. Apart from the case of economic benefit, the social question came to play an important role, too: "The redefinition of equality of educational opportunity cleared the way for the triumph of vocationalism in American education" (Lazerson and Grubb 1974, p. 25 ff.). As many commission reports clarify, since the beginning of the 1920 s it was undisputed that the American public school system should be vocation-oriented. Vocationalism was made a national priority, even becoming a topic in Wilson's presidential campaign. In 1917, the demand for vocationalism resulted in the Smith-Hughes Act, also called the Vocational Act. As a result, vocationalism, taken as the vocational orientation of curricula, now extended beyond high schools; it had become a matter of establishing vocational education in the whole American school system.

\section{Spread and Ambivalence of Vocationalism}

The increasing importance of vocationalism in America between the 1920s and 1970 s is reflected in legislation that continually strengthened the financial basis for the corresponding claims. The influence of the vocationalism movement on the American school system is furthermore shown in its general orientation during that era. Schools sought to convey job skills and introduce learners to their future occupational activity. Sometimes, even a specialisation and fragmentation of the curriculum for individual pupils was favoured. Thus, the industrial order had reached into the American school system (Lazerson and Grubb 1974, p. 50) in way that was quite comprehensive and distinct from the German schooling system.

Kantor and Tyack (1982) claim that at the beginning of the twentieth century it was a widespread idea among reformers that it was schools' responsibility to train young people for work. Indeed, American schools have undergone many transformations throughout the twentieth century and have had to adjust to the needs and concerns of many different interest groups. This particular reorientation is mainly due to the rather dramatic transformation of work between 1880 and 1930, and in particular those regarding specialisation, management and division of labour. An explicitly vocation-oriented education was seen as the solution for the emerging challenges and problems in the world of work and the labour market at this time (Kantor and Tyack 1982, p. 43).

Importantly, vocationalism was not restricted to the upper secondary level, with this trend being influential at the level of colleges and universities (Hyland 2001, p. $178 \mathrm{ff}$.). Consistent with and aligned to the vocationalism trend, around 1920 the notion of 'adult education' appeared and was characterised by something more than a voluntary approach to self-improvement for its own sake. Rather, it was seen as a matter of social advancement and a deliberate focus on the accomplishment of workrelated tasks (Kett 1994, p. XII ff.).

To many historians of education, the impact of vocationalism was quite surprising. Despite its questionable success, the American public were convinced of the usefulness of the vocationalisation idea, in particular with regard to the opening up of opportunities for underprivileged youths (Tyack and Justice 2003, p. 188). 


\section{Efficiency as an Argument Against Vocationalism: Snedden's Utopia "1960"}

So far, 'efficiency' and 'vocationalism' have been presented as closely related and mutually strengthening concepts and as explicit options for educational reforms. However, for Snedden, its was actually efficiency as a formal principle which, many years after his debate with Dewey, made him question the usefulness of vocational schools and their vocationalism tendencies. In 1931, he published an educational vision which he deliberately presented as a continuation of existing trends: "American High Schools and Vocational Schools in 1960". His vision describes the visit of a Chinese educational delegation to the USA at the beginning of the 1960s: After the successful advancement of their elementary school, the Republic of China would like to profit from the US experience of reforms on the upper secondary level and of the developments in the higher education sector, in order to take corresponding measures at home.

In Snedden's vision, efficiency and democracy are the highest principles (Snedden 1931, p. 17). Surprisingly, in his vision, all pupils are first of all introduced to the main cultural and political achievements. He argued explicitly against vocational part-time schools (Snedden 1931, p. 97). Instead, he argued for high schooling for all young people up to age 18, premised on the argument that the 'quasi vocationalism' of the existing high schools had failed: "By 1935, it had become evident that the compulsory continuation schools offered practically no useful contributions to genuine vocational education" (Snedden 1931, p. 108). Snedden considered the pupils to be too young and already too much involved in the world of work, and the field of school activities to be too large for them to be pedagogically effective. Furthermore, he doubted that the teachers were adequately trained for these vocational purposes. Not only had traditional apprenticeships virtually vanished in all occupational fields by 1930, but that the evening school provision had also largely become redundant, as well. Based on this evaluation, he preferred a general, not vocation-oriented high school, and vocational schools would only be available as schools for adults and beyond compulsory schooling. The role of education was primarily to offer advice and guidance, and to enable learners to enter the vocational schools for adults after the general, pre-vocational phase, because the vocational orientation and desire of youths only develop around age 15 . In a first phase, up to around age 18, education was, therefore, a matter of imparting values like competence and responsibility (Snedden 1931, p. 79). In this way, Snedden (1931) had turned completely against the idea of extensive vocationalism and the establishment of part-time vocational schools because of its lack of efficiency. The criterion of external efficiency as the relation of the educational system to the world of work had proved too ineffective and was, therefore, rejected by Snedden.

\section{Conclusion}

Even though American vocational education is not at the centre of today's discourse on vocational pedagogy and educational policy, a reconstruction of the respective controversies offers valuable insights by highlighting the complexity and the contingency of the struggles over the relations between education and work. Both 
semantic and the institutional implementation issues are country-specific, yet the formal principles can be found in a variety of contexts. Ultimately, the request for 'efficiency' might well come to play an important role in the European and the German vocational education system as well.

In examining recent developments within American vocational education, it is remarkable how Snedden's vision has now become topical. Historically, the issue of qualification for employment in the industry and service sector was mainly discussed in relation to a vocational orientation of the schools. In reality, however, today's American high schools have little relation to vocations, while the community colleges on a higher level in the education system have developed into vocational schools for adults (Grubb 1999). In this respect, contemporary American high schools with their marginal vocational orientation resemble neither Dewey's nor Snedden's views. External efficiency in terms of a request for vocational orientation has its difficulties, and this had led Snedden to abandon his original scheme. It may be seen as irony of fate unforeseeable to all involved actors that efficiency has been put forward as an argument for general education and against an early orientation towards skills development and practical use.

\section{References}

Bennett, Ch. (1937). History of manual and industrial education, 1870-1917. Peoria, IL: The Manual Art Press.

Berryman, S. E., \& Bailey, T. R. (1992). The double helix of education \& the economy. New York: TC.

Cooley, E. (1912). Vocational education in Europe: Report to the Commercial Club of Chicago. Chicago: CCC.

Copa, G., \& Bentley, C. B. (1991). Vocational education. In P. W. Jackson (Ed.), Handbook of research on curriculum (pp. 891-944). New York: Macmillan.

Davenport, E. (1914). Education for Efficiency: A discussion of certain phases of the problem of universal education with special reference to academic ideals and methods. Revised Edition. Boston: D.C. Heath (EA 1909).

Deissinger, Th. (1994). The evolution of the modern vocational training systems in England and Germany: A comparative view. Compare. A Journal of Comparative Education, 24(1), 17-36.

Dewey, J. (1911). Culture and culture values. In P. Monroe (Ed.), A cyclopaedia of education, volume 1 (pp. 238-239). New York: Macmillan.

Dewey, J. (1916). Democracy and education. New York: The Free Press.

Drost, W. (1967). David Snedden and education for social efficiency. Madison: University of Wisconsin Press.

Eliot, Ch. W. (1906). Education for efficiency and the new definition of the cultivated man. Boston: Houghton Mifflin.

Georg, W. (1992). Education and vocational training in Japan. In W. Heidemann, A. Paul-Kohlhoff, \& C. Zeuner (Eds.), Qualification in the automobile industry (pp. 38-60). Marburg: Schüren.

Gonon, Ph. (1998). Das internationale Argument in der Bildungsreform: Die Rolle internationaler Bezüge in den bildungspolitischen Debatten zur schweizerischen Berufsbildung und zur englischen Reform der Sekundarstufe II. Bern: Peter Lang.

Gonon, Ph. (2000). Education, not democracy? The apolitical Dewey. Studies in Philosophy and Education, 19(1-2), 141-157.

Gonon, Ph. (2002). Georg Kerschensteiner-Begriff der Arbeitsschule. In V. Dieter Jürgen Löwisch (Ed.), Werkinterpretationen pädagogischer Klassiker. Darmstadt: Wissenschaftliche Buchgesellschaft.

Greinert, W. (2005). Mass vocational education and training in Europe. Classical models of the 19th century and training in England, France and Germany during the first half of the 20th. Cedefop Panorama series, 118. Luxembourg: Office for Official Publications of the European Communities. 
Grubb, N. W. (1999). Honored but invisible: An inside look at teaching in community colleges. New York: Routledge.

Herbst, J. (1996). The once and future school: Three hundred and fifty years of American Secondary Education. New York, London: Routledge.

Hyland, T. (2001). Vocationalism, work and the future of higher education. Journal of Vocational Education and Training, 53(4), 677-684.

Kantor, H., \& Tyack, D. (1982). Work, youth and schooling: Historical perspectives on vocationalism in American education. Stanford: Stanford University Press.

Kerschensteiner, G. (1911). Three lectures on vocational education. Chicago: U. Press.

Kett, J. (1994). The pursuit of knowledge under difficulties: From self-improvement to adult education in America, 1750-1990. Stanford: Stanford University Press.

King, I. (1913). Education for social efficiency: A study in the social relations of education. New York: Appleton.

Kliebard, H. (1986). The struggle for the American curriculum 1893-1958. Boston: Routledge.

Kliebard, H. (1999). Schooled to work: Vocationalism and the American curriculum 1876-1946. New York: Teachers College.

Knoll, J. (1993). Dewey versus Kerschensteiner: Der Streit um die Einführung der Fortbildungsschule in den USA 1910-1917. Pädagogische Rundschau, 47, 131-145.

Koch, R. (1998). Duale berufliche Ausbildung zwischen Bildungsnachfrage und Qualifikationsbedarf. Bielefeld: Bertelsmann.

Lazerson, M., \& Grubb, N. W. (1974). Introduction. In W. Grubb, \& M. Lazerson (Eds.), American education and vocationalism. A documentary history 1870-1970. New York: Teachers College Press.

Leake, A. H. (1913). Industrial education: Its problems, methods and dangers. Boston: Houghton Mifflin.

Monroe, P. (1913). Vocational education. In P. Monroe (Ed.), Cyclopaedia of education (vol. V, (p. 740)). New York: MacMillan.

Monshheimer, O. (1968). Erziehung für Übermorgen: Erziehung für die technisierte Welt der amerikanischen Leistungsgesellschaft. Weinheim: Beltz.

Münk, D. (2006). The impact of European strategies and priorities. In P. Descy, M. Tessaring (Eds.), Modernising vocational education and training: Fourth report on vocational training research in Europe: background report. Luxembourg: EUR-OP (Cedefop reference series Thessaloniki, zus. mit Bohlinger).

Schütte, F. (2001). Die Arbeit am "Projekt der Moderne"-Der berufspädagogische Wissenstransfer zwischen Deutschland und der USA 1906-1998. In H. Reinisch, et al. (Ed.), Modernisierung der Berufsbildung in Europa (pp. 173-182). Opladen: Leske \& Budrich.

Snedden, D. (1910). The problem of vocational education. Boston: Houghton Mifflin.

Snedden, D. (1931). American High Schools and Vocational Schools in 1960. New York: Teachers College, Columbia University.

Tyack, D., \& Justice, B. (2003). Vocational Education in the U.S.-Some Historical Perspectives. In J. Oelkers (Ed.), Futures of education II-Essays from an Interdisciplinary Symposium (pp. 179-196). Bern: Peter Lang.

Wright, J. C., \& Allen, Ch. R. (1929). Efficiency in education: A study of the applications of the principles of efficiency to educational administration, supervision and methods of teaching. New York: Wiley.

Philipp Gonon was born on October 15th in Flensburg (Germany). Since 2004, he holds the chair of VET and Teacher Training at the University of Zurich (Switzerland). His exploratory focus are International and comparative approach to VET and Further Education, Philosophy and History of (Vocational) Education and Quality assurance and Evaluation. 